\title{
SOME COMMENTS ON RULEMAKING AT THE WORLD INTELLECTUAL PROPERTY ORGANIZATION
}

\author{
EDWARD KWAKWA*
}

\section{INTRODUCTION}

An organization's ability to reflect and respond to the changing needs and demands of its constituents by adopting rapid and effective means of rulemaking is one of its most important features. This ability is particularly important in the field of intellectual property. Rules concerning intellectual property have been adopted traditionally by the treaty method. As a result of rapid advances in technology, however, traditional treaty-making processes are now unsuited to the realities of intellectual property law. This poses a challenge to the World Intellectual Property Organization (WIPO), the specialized agency of the United Nations (U.N.) whose mandate is the promotion and protection of intellectual property worldwide. In order to ensure WIPO's continued relevance, viability, and legitimacy in an increasingly globalized world, the Organization must adapt its traditional rulemaking processes by adopting more rapid, transparent, effective, and politically acceptable means of norm creation. This paper discusses the extent to which advances in technology and other developments in related areas have influenced the ways in which WIPO addresses the issue of rulemaking in the field of intellectual property. ${ }^{1}$

Copyright $\odot$ by Edward Kwakwa

* LL.B., University of Ghana; LL.M., Queen's University; LL.M., J.S.D., Yale Law School. Assistant Legal Counsel, World Intellectual Property Organization (WIPO), Geneva. This is a modified version of a lecture delivered at Duke Law School on October 23, 2000, on the occasion of the Duke Journal of Comparative and International Law Speaker Series inaugural lecture. The views expressed here are my personal views and are not necessarily shared by WIPO or by the United Nations.

1. In this paper, I draw specifically on my experience as a lawyer at two different international, intergovernmental organizations: the World Intellectual Property Organization (WIPO) and the World Trade Organization (WTO). These organizations represent two different institutions and structures within the paradigm of intergovernmental organizations: WIPO is not part of the United Nations proper, but is a specialized agency of the United Nations; and the WTO is neither an organ nor a specialized agency of the United Nations, but an autonomous international organization. At WTO, I worked as a Legal Affairs Officer in the Technical Cooperation 


\section{RULEMAKING IN GENERAL AND IN THE FIELD OF INTELLECTUAL PROPERTY}

Since most of my examples are drawn from my present job as Assistant Legal Counsel at WIPO, I will begin this discussion of rulemaking in the intellectual property field with a brief description of WIPO in order to provide the context in which the subsequent discussion takes place.

\section{A. The World Intellectual Property Organization}

The Convention Establishing the World Intellectual Property Organization (the WIPO Convention) was signed in 1967, and entered into force in 1970. ${ }^{2}$ WIPO's origins pre-date the WIPO Convention to 1883 and 1886, the years in which the Paris Convention for the Protection of Industrial Property and the Berne Convention for the Protection of Literary and Artistic Works were adopted. ${ }^{3}$ Legal issues surrounding intellectual property were relevant and important during, and even before the 1880s. In 1883, the year in which the Paris Convention was adopted, Johannes Brahms composed his third Symphony, Robert Louis Stevenson wrote Treasure Island, and John and Emily Roebling completed construction of New York's Brooklyn Bridge. ${ }^{4}$ All of these works of intellectual property required protection.

WIPO is responsible for promoting the protection of intellectual property throughout the world and for the administration of various multilateral treaties, which address the legal and administrative aspects of intellectual property. The Secretariat of WIPO comprises about 1000 staff members from some 85 countries. The recently approved budget of the Organization for the 2002-2003 biennium is 678.4 million Swiss francs or 410 million U.S. dollars at today's rate of

and Training Division; at WIPO, I am working as the Assistant Legal Counsel to the Organization.

2. Convention Establishing the World Intellectual Property Organization, July 14, 1967, 21 U.S.T. 1770, 828 U.N.T.S. 3 (last amended Sept. 28, 1979). For a detailed account of the history of WIPO, see generally WORLD INTELLECTUAL PROPERTY ORGANIZATION, InTRoduction to InTELLECTUAL Property: THEORY AND PRACTICE (1997).

3. Paris Convention for the Protection of Industrial Property, Mar. 20, 1883, 21 U.S.T. 1538, 828 U.N.T.S. 305 (last revised July 14, 1967) [hereinafter Paris Convention]; Berne Convention for the Protection of Literary and Artistic Works, Sept. 9, 1886, 828 U.N.T.S. 221 (last revised July 24, 1971) [hereinafter Berne Convention].

4. See generally World Intellectual Property Organization, General INFORMATION: WORLD INTELlectual PROPERTy ORgANiZATION, WIPO Publ. No. 400(E) (2001). 
exchange. ${ }^{5}$ WIPO is largely self-financing. The Organization generates over eighty-five percent of its income from fees paid by private sector users of the international registration services provided by the WIPO Secretariat. ${ }^{6}$ Six percent of the Organization's income is received from its 177 member states, and the remaining nine percent of income comes from the sale of WIPO publications, fees related to the arbitration and mediation services provided by WIPO, and interest earnings. $^{7}$

Membership in WIPO is open to (i) any state member of the Paris or Berne Union; (ii) any other state, provided it is a member of the U.N., any Specialized Agency of the U.N., IAEA, or party to the Statute of the International Court of Justice; and (iii) any state that is invited by the WIPO General Assembly to join the Organization. ${ }^{8}$

\section{B. The Problem with Traditional Rulemaking Processes}

International intellectual property regulation and oversight requires a system of norm-creation that is flexible enough to adapt to a dynamic, fast-paced, and technologically driven area of law. This fundamentally conflicts with the primary historical structure and means of rulemaking in international law-the multilateral treatymaking process. WIPO has traditionally used the multilateral treatymaking process to create rules under its auspices. This process has drawbacks. Treaty-making in the intellectual property field has been slow and time-consuming. Most of the twenty-three treaties adminis-

5. Revised Draft Program and Budget 2002-2003, WIPO Doc. WO/PBC/4/2, at http:// www.wipo.int/eng/document/govbody/wo_pbc/doc/4_4.doc (Sept. 20, 2001).

6. Some of the WIPO Treaties relating to patents, trademarks and industrial designs ensure that a single international registration or filing will have effect in any of the designated or relevant member states. The WIPO Secretariat's services under these treaties aim at simplifying and reducing the cost of making individual or à la carte applications or filings in each country in which protection for a given intellectual property right is sought. General information is available at http://www.wipo.int/about-wipo/en (last visited Nov. 23, 2001).

7. See Annual Report 46, WIPO Publ. No. 441(E) (2001). WIPO does not have a system of weighted voting. Each member state belongs to one of fourteen contribution classes, but their rights remain the same, irrespective of the contribution class to which they belong. The effect of the contribution system is that unlike the United Nations, for example, where the United States pays some twenty-two percent of the Organization's regular budget, at WIPO the United States pays less than one percent of the operating budget of the Organization. The five largest contributing countries (France, Germany, Japan, United Kingdom, and United States) each contribute under one percent of the Organization's budget.

8. See Convention Establishing the World Intellectual Property Organization, supra note 2 , at art. 5. It is clear that any entity wishing to join WIPO will have to satisfy the threshold question of statehood. This contrasts with international organizations like the WTO, where non-state entities, such as Hong Kong, Macau, and the European Communities are members. 
tered by WIPO were promulgated through a complicated process that normally entailed the establishment of a Committee of Experts, whose deliberation sometimes lasted several years. The Committee's deliberations would usually be followed by the convention of a preparatory committee for a diplomatic conference, and finally by a diplomatic conference to adopt the treaty in question. Even if this process ran smoothly, it could take over five years to draft, negotiate, and adopt a treaty. Furthermore, a treaty adopted in this manner would only bind those states that ratify or accede to it.

The treaty-making process could be delayed further by the fact that both international and domestic requirements need to be fulfilled before a treaty comes into force in the states concerned. It generally takes an inordinate amount of time to bring a treaty into force across a geographically effective and pertinent area. The so-called "Internet" treaties are a good example. In 1996, WIPO member states adopted the WIPO Copyright Treaty (WCT) and the WIPO Performances and Phonograms Treaty (WPPT). ${ }^{9}$ The treaties update the international protection of copyright and related rights by taking into account, and including rules that better conform to, the realities of the Internet age. At the time of adoption, WIPO anticipated that the treaties would receive the requisite thirty instruments of ratification or accession quickly in order to enter into force in timely fashion. This was considered crucial in light of the subject matter that the treaties covered. As of October 2001, however, the treaties have received only twenty-eight and twenty-six such instruments respectively. ${ }^{10}$ Thus, these two "Internet" treaties, which should have entered into force some three or more years ago, in all likelihood will not enter into force until the first half of 2002, more than six years after their adoption. During this time the treaties have not fulfilled their pur-

9. WIPO Copyright Treaty, Dec. 20, 1996, 36 I.L.M. 65, WIPO Publ. No. 226(E) [hereinafter WCT]; WIPO Performances and Phonograms Treaty, Dec. 20, 1996, 36 I.L.M. 76, WIPO Publ. No. 227(E) [hereinafter WPPT].

10. The WCT has been ratified or acceded to by the following twenty-eight states: Argentina, Belarus, Bulgaria, Burkina Faso, Chile, Colombia, Costa Rica, Croatia, Czech Republic, Ecuador, El Salvador, Georgia, Hungary, Indonesia, Japan, Kyrgyzstan, Latvia, Lithuania, Mexico, Panama, Paraguay, Peru, Republic of Moldova, Romania, Saint Lucia, Slovakia, Slovenia, and the United States. With the recent accession of Gabon and the Ukraine, the WCT has received the requisite 30 instruments of ratification and will come into force on March, 6, 2002. See World Intellectual Property Organization, Actions in Respect of Treaties Administered by WIPO Not Yet In Force, at http://www.wipo.int/treaties/docs/english/u-page31.doc (Oct. 22, 2001). The WPPT has been ratified or acceded to by all the above countries, with the exception of Gabon, Indonesia, Japan, Kyrgyzstan, Peru, and the Ukraine. Albania and Mali have acceded to the WPPT, but not to the WCT. See id. 
pose of providing adequate solutions to changes resulting from new economic, social, cultural, and technological developments.

Most disappointing is the fact that certain treaties may never enter into force, even after considerable human and financial resources have been expended on their drafting, negotiation, and adoption. A classic example of this is the Treaty on the Protection of Intellectual Property in Respect of Integrated Circuits. ${ }^{11}$ The treaty was adopted in 1989, after more than five years of negotiations. As of October 2001, twelve years after its adoption, the treaty has been ratified by only one country and acceded to by another. ${ }^{12}$ Although it has been incorporated into the World Trade Organization's TRIPS Agreement, ${ }^{13}$ it seems unlikely that the treaty ever will enter into force. ${ }^{14}$

Intellectual property is one of the most rapidly growing areas in the practice of law, both nationally and internationally. This naturally raises the potential for an increasing number of international disputes involving various forms of intellectual property. It is imperative that intellectual property law remain current, responding to today's fastpaced technological developments; this imperative, however, further complicates the treaty-making process. In addition to the drafting, negotiation, and adoption processes, treaty amendment or revision often requires a similarly time-consuming process of consultations and negotiations. Such amendments or revisions also are subject to the same requirements of accessions or ratifications before entry into force. The lack of uniformity in the speed with which different states initiate and complete their domestic procedures for adherence to such amendments may result in a complicated and asymmetrical situation among states that are parties to the same agreement, but not to subsequent amendments or revisions. This poses serious problems for the international intellectual property regime, a regime that requires frequent amendments in order to update the treaties concerned.

11. Treaty on Intellectual Property in Respect of Integrated Circuits, May 26, 1989, 28 I.L.M. 1477, WIPO Publ. No. 202(E).

12. These are Egypt and Saint Lucia respectively. The treaty was due to come into force after the deposit of five instruments of ratification or accession. See supra note 11, at art. 16(1).

13. Agreement on Trade-Related Aspects of Intellectual Property Rights, Apr. 15, 1994, art. 1(3), Marrakesh Agreement Establishing the World Trade Organization [hereinafter WTO Agreement], Annex 1C, Legal Instruments-Results of the URUGUay Round vol. 31, 33 I.L.M. 81 (1994) [hereinafter TRIPS Agreement].

14. It is instructive to note that the United States and Japan, which together own about seventy percent of the semi-conductor industry for integrated circuits, decided not to adhere to the treaty. 


\section{The Effect of Overlapping Mandates or Competing Legal Regimes on Rulemaking Processes: the Example of Dispute Settlement}

A further difficulty arises with respect to rulemaking when the initial problems or interests of states change in the intervening period during negotiations on the treaty's text. An illustration of this problem is the WIPO draft Treaty on the Settlement of Disputes Between States in the Field of Intellectual Property. ${ }^{15}$ This treaty was initially proposed and discussed in 1989. At that time, there was widespread interest in the treaty's subject among all the WIPO member states. In response to this interest, the governing bodies of WIPO established what was referred to as a Committee on the Settlement of Intellectual Property Disputes between States. ${ }^{16}$ The Committee started work in 1990 and held as many as eight sessions between 1989 and 1996.

In 1994, the member states of the General Agreement on Tariffs and Trade (GATT) met at Marrakesh, Morocco, and signed the Agreement Establishing the World Trade Organization. ${ }^{17}$ That Agreement included the Agreement on Trade-Related Aspects of Intellectual Property Rights (TRIPS) ${ }^{18}$ and the Dispute Settlement Understanding (DSU). ${ }^{19}$ The establishment of the World Trade Organization (WTO) seems to have dissuaded some WIPO member states from supporting a mechanism for settling intellectual property disputes between states under WIPO auspices.

15. Proposed Treaty on the Settlement of Disputes Between States in the Field of Intellectual Property, Apr. 30, 1997, WIPO Doc. No. WO/GA/XX1/2, at www.wipo.orglengldocument। govbodylwo_gb_galdoclga21_2.doc (last visited Nov. 25, 2001).

16. WIPO Doc. No. AB/XX/2, Annex. A, at 17 (May 31, 1989) (on file with the Duke Journal of Comparative and International Law).

17. WTO Agreement, supra note 13. The five main functions of WTO are provided in Article III of WTO's constituent instrument. They are (i) to facilitate the implementation, administration, and operation, and to further the objectives of the WTO Agreement; (ii) to provide a forum for negotiations among WTO members and a framework for the implementation of the results of those negotiations; (iii) to administer the Dispute Settlement Understanding of the WTO; (iv) to administer the Trade Policy Review Mechanism of the WTO; and (v) to cooperate with the IMF and the World Bank "[w]ith a view to achieving greater coherence in global economic policy-making." Id. at art. 3. See also General Agreement on Tariffs and Trade 1994, Apr. 15, 1994, Marrakesh Agreement Establishing the World Trade Organization, Annex 1A, LEGAL InSTRUMENTS-RESUlTS OF THE URUGUAY ROUND vol. 1, 33 I.L.M. 1154 (1994) [hereinafter GATT 1994].

18. See supra note 13.

19. Understanding on Rules and Procedures Governing the Settlement of Disputes, Apr. 15, 1994, Marrakesh Agreement Establishing the World Trade Organization, Annex 2, LEGAL INSTRUMENTS-RESULTS OF THE URUGUAY ROUND vol. 31, 33 I.L.M. 112 (1994). 
There were strong arguments in support of the proposal to establish a dispute settlement mechanism under WIPO, which would be independent of the WTO dispute settlement body. WIPO advocated an independent WIPO forum for dispute settlement because not all WIPO member states are WTO members. ${ }^{20}$ Indeed, significant economies, such as Russia, continue to remain outside the WTO system. ${ }^{21}$ Such states are therefore excluded from participating in the WTO dispute settlement system.

Proponents of a dispute settlement mechanism at WIPO also favored an internal settlement mechanism because not all intellectual property treaties are covered by the WTO dispute settlement mechanism. WIPO administers twenty-three treaties in the intellectual property area; the WTO's TRIPS Agreement only incorporates the substantive provisions of a few of those WIPO Agreements. ${ }^{22}$ Furthermore, not all intellectual property disputes are subject to resolution through the WTO dispute settlement system. For example, Article 9 of the TRIPS Agreement expressly excludes moral rights from its purview. ${ }^{23}$

There are other important reasons in favor of the establishment of a dispute settlement mechanism at WIPO. First, WIPO is the only intergovernmental organization whose mandate is exclusively in the area of intellectual property law, an area that is increasingly specialized and technically sophisticated. Indeed, WIPO has an ongoing relationship of cooperation with its member states' intellectual property administrations, as well as numerous regional intergovernmental organizations dealing with intellectual property. Further, almost 200 international non-governmental organizations (NGOs) act as accred-

20. As of October 2001, the WTO had 142 members, and WIPO had 177 member states.

21. After fifteen years, negotiations for China's terms of membership and its accession to the WTO have finally been resolved. On December 11, 2001, China will become a full member of the WTO. See Press Release, World Trade Organization, China to join on 11 December, Chinese Taipei's membership also approved (Nov. 11, 2001).

22. These are the Paris Convention for the Protection of Industrial Property, the Berne Convention for the Protection of Literary and Artistic Works, the Rome Convention for the Protection of Performers, Producers of Phonograms and Broadcasting Organizations, and the Treaty on Intellectual Property in Respect of Integrated Circuits. See TRIPS Agreement, supra note 13 , at art. 1(3).

23. Article 9(1) of the TRIPS Agreement provides: "Members shall comply with Articles 1 through 21 of the Berne Convention (1971) and the Appendix thereto. However, Members shall not have rights or obligations under this Agreement in respect of the rights conferred under Article 6bis of that Convention or of the rights derived therefrom." See TRIPS Agreement, supra note 13, at art. 9(1). Article 6bis of the Berne Convention concerns the moral rights of authors, namely to claim authorship, to object to certain modifications and other derogatory actions, and means of redress. See Berne Convention, supra note 3, at art. 6 bis. 
ited observers at the meetings of WIPO's member states. ${ }^{24}$ Second, providing a dispute settlement mechanism within WIPO would result in greater uniformity and consistency in the application and interpretation of intellectual property laws. Third, proponents of a dispute settlement mechanism at WIPO argued that this would permit states to settle their intellectual property disputes in a less politically charged atmosphere, because there is no threat of trade sanctions at WIPO. ${ }^{25}$

There were, however, also strong arguments in favor of a dispute settlement system at the WTO. Proponents asserted that the TRIPS Agreement incorporates the substantive provisions of the more important intellectual property conventions, such as the Paris and Berne Conventions, and therefore a WTO dispute settlement system would cover all important aspects of intellectual property disputes. Although the main intellectual property treaties had dispute settlement provisions, no state had ever resorted to them. In contrast, WTO members had invoked the dispute settlement provisions under the TRIPS Agreement on several occasions during the WTO's short existence. This was seen as indicating that the earlier dispute settlement provisions in the WIPO treaties were less than effective. ${ }^{26}$ Second, proponents argued that states had a big stake in solving their intellectual property disputes because of the direct harm they perceived to

24. Those NGOs that are accredited as observers are allowed to participate in the meetings of WIPO's member states, albeit with limited rights. For example, the NGOs do not have voting rights, they only make their statements after the member states have made theirs, and NGOs are not allowed to submit proposals, amendments or motions.

25. Unlike the WTO, there is no enforcement power or mechanism in WIPO, as is the case in most other intergovernmental organizations. The WTO is an exception in this regard.

26. There are several examples of WIPO-administered intellectual property treaties and conventions that provide for dispute settlement by the International Court of Justice. For example, the Berne Convention provides:

Any dispute between two or more countries of the Union concerning the interpreta-

tion or application of this Convention, not settled by negotiation, may, by any one of

the countries concerned, be brought before the International Court of Justice by appli-

cation in conformity with the Statute of the Court, unless the countries concerned agree on some other method of settlement.

Berne Convention, supra note 3, at art. 33; see also Paris Convention, supra note 3, at art. 28 (using identical language); Patent Cooperation Treaty, June 19, 1970, art. 59, 28 U.S.T. 7645, 9 I.L.M. 978 (1970) (entered into force Jan. 24, 1978) (also using identical language). The reluctance of states to bring their disputes in such technical areas as intellectual property to the ICJ is well known. Complaints include the fact that reservations are permitted to the jurisdiction of the ICJ, the length of time it takes before decisions are handed out, and the fact that private claimants would need to have their claims espoused by their states at the ICJ. It seems counterintuitive to argue, however, that a dispute settlement provision is not effective because it has not been used. An equally plausible argument would be that the mere existence of those provisions has had a restraining influence on the outbreak of such disputes. 
their trade and other economic interests (i.e., intellectual property and trade were vitally and inextricably linked). Therefore, they argued, it was more logical to settle intellectual property disputes under the auspices of a trade body. Third, it was argued that refraining from establishing a second dispute settlement mechanism at WIPO would minimize the risk of conflicts between two rival regimes and eliminate the potential for duplication.

Ultimately, the failure of the WIPO draft Treaty for the Settlement of Disputes, in the face of the establishment of a dispute settlement mechanism under the WTO framework, illustrates the significance of competing legal regimes or the existence of intergovernmental organizations with mandates that create the potential for competing jurisdiction or duplication in efforts. ${ }^{27}$ In the context of treaty-making, the problem arose because WIPO traditionally had been the only intergovernmental organization with a mandate to adopt norms in the intellectual property field. This situation changed when the TRIPS Agreement was adopted as part of the WTO Agreement, thus creating uncertainty as to the appropriate forum for the creation of intellectual property norms.

\section{D. "Soft Law" as a Means of Norm Creation}

The process of rulemaking in international law encompasses a wide array of means, methods, and procedures. Whatever the means or process of rulemaking, a common goal is pervasive: to produce rules, standards or guidelines that purport to govern the future conduct of particular actors over a specified range of activity. The most established form of rulemaking is the multilateral treaty-making process, as discussed above. Other forms of rulemaking include nonbinding agreements-declarations and decisions of international organizations, which include certain widely supported and generally accepted resolutions or declarations of the U.N. General Assembly (UNGA). In this regard, it is instructive that some international organizations have effectively used certain "soft law" instruments other than treaties to generate new international law norms. The term "soft law" generally is used to refer to certain categories of norms, technically non-binding in nature, that states nonetheless follow in practice or to which they at least subscribe. Such norms are sometimes la-

27. I have elaborated on what I perceive to be increasing conflicts or overlaps of jurisdiction between and among, in particular, international economic organizations. See Edward Kwakwa, Institutional Perspectives of International Economic Law, in PERSPECTIVES IN INTERNATIONAL ECONOMIC LAW (Asif Qureshi ed., forthcoming 2001). 
beled "guidelines," "recommendations," "resolutions," or "standards." The concept of soft law has generated controversy in discussions of the sources of international law. ${ }^{28}$ While it is not the purpose of this essay to discuss the actual status of soft law in international law, it will suffice to point out that various forms of soft law have been established effectively in various fora and seem to be adhered to by states, as illustrated by the discussion below. ${ }^{29}$

The most frequently cited forms of soft law are certain resolutions and declarations of the UNGA. While the U.N. Charter does not provide the General Assembly with legislative powers, except for specifically enumerated cases relating to procedural and budgetary matters, this limitation has not precluded the Assembly's rulemaking activities. The Assembly has promulgated multilateral conventions to which all states may become parties, and states have demonstrated acceptance of specific resolutions or declarations, guidelines, and minimum rules or standards. An example is the Declaration on Principles of International Law Concerning Friendly Relations and Cooperation among States in Accordance with the Charter of the U.N., ${ }^{30}$ adopted by the General Assembly without dissent, and now generally accepted as a declaration of principles and rules of international law. An even more prominent example is the 1948 Universal Declaration of Human Rights. ${ }^{31}$

Soft law, whether in the form of declarations, recommendations, guidelines or codes, can impact the behavior of states and other relevant entities significantly. The increasing use of soft law is widely recognized. Certain multilateral treaties now contain references to "internationally recognized norms and standards" and "established principles" of international law. ${ }^{32}$ There has long been debate as to

28. On this subject, see generally Paul Szasz, General Law-Making Processes, in THE United NATIONS AND INTERNATIONAL LAW 27-64 (Christopher Joyner ed., 1997); Frederic Kirgis, Specialized Law-Making Processes, in THE United NATIONS AND InTERNATIONAL LAW, supra note 28, at 65-94; Panel Discussion of the American Society of International Law, $A$ Hard Look at Soft Law, Proc. AM. Soc. INT’L L. 371-95 (1998).

29. See generally Christine Chinkin, The Challenge of Soft Law: Development and Change in International Law, 38 ICLQ 850 (1989); Tadeusz Gruchalla-Wesierski, A Framework for Understanding 'Soft Law, 30 MCGILL L.J. 37 (1984).

30. Declaration on Principles of International Law Concerning Friendly Relations and Cooperation among States in Accordance with the Charter of the United Nations, Oct. 24, 1970, G.A. Res. 2625, 25 U.N. GAOR Supp. (No. 28) at 121, U.N. Doc. A/8028 (1970).

31. Universal Declaration of Human Rights, Dec. 10, 1948, G.A. Res. 217A(III), U.N. Doc. $\mathrm{A} / 810$, at 71

32. See, e.g., Rome Statute of the International Criminal Court, adopted and opened for signature July 17, 1998, art. 21(1), U.N. Doc. A/Conf. 183/9 (1998), 37 I.L.M. 999. 
whether state practice and/or opinio juris is evidenced not only in formal treaty texts, but also in UNGA resolutions and decisions of intergovernmental organizations. According to one view, the general acceptance of a principle by states, at an international conference or at the UNGA, is sufficient to transform such a principle into a "generally accepted rule" of international law, as envisaged under Article 38 of the Statute of the International Court of Justice. ${ }^{33}$ According to another view, however, such principles only become accepted as international law when they are incorporated into treaties or when they ripen into custom. ${ }^{34}$

Soft law is used frequently as a norm-creation technique by international organizations. While the constituent instruments of most international organizations establish the procedure by which member states may promulgate rules governing activities within the organization's competence, the form and format of those procedures vary widely.

One of the most unique examples of non-traditional normcreation is provided by the International Labor Organization (ILO). ${ }^{35}$ The process of treaty-making at the ILO is entrusted not only to governments, but also to the International Labor Conference, the plenary body of the ILO whose composition per member state is two government representatives (one workers' representative and one employers' representative). ILO treaties are not signed, but are adopted by the Conference by a majority of two-thirds of the votes cast. Member states are obliged then to submit the treaty to their competent authorities for enactment of conforming domestic legislation. $^{36}$ Governments whose domestic legislatures approve the treaty must "ratify" the treaty, while governments whose legislatures do not approve the treaty are required to report periodically to the ILO on

33. Statute of the International Court of Justice, June 26, 1945, chap. II, art. 38, 59 Stat. 1031, 33 U.N.T.S. 993.

34. See generally G.M. DANILENKO, LAW-MAKING IN THE INTERNATIONAL COMMUNITY 203-210 (1993); IAN Brownlie, Principles of Public InTERnational LAW 14, 694-696 (5th ed. 1998); Michael AKeHurst, A Modern InTroduction to InTERnAtional LaW 37-38 (5th ed. 1984).

35. Constitution of the International Labor Organization, June 28, 1919, Preamble to Part XIII of the Treaty of Peace between the United States of America, the British Empire, France, Italy, Japan and Poland, June 28, 1919 [hereinafter Treaty of Versailles], 225 Consol. T.S. 188, 4 U.K.T.S., amended on several occasions and current revision reprinted in ILO, CONSTITUTION OF THE INTERNATIONAL LABOUR ORGANIZATION AND STANDING ORDERS OF THE INTERNATIONAL LABOUR CONFERENCE 5-24 (1980). It is important to note that the Treaty of Versailles and the current ILO Constitution are different documents.

36. Id. art. 19(2) 
the extent to which their law and practice are consistent with the treaty, as well as the obstacles to ratification of the treaty. ${ }^{37}$ The ILO Conference also has the power to supplement ILO treaties with recommendations adopted contemporaneously, and which frequently are aimed at supplying details to the more general treaty provisions. Such recommendations are also subject to reporting requirements. ${ }^{38}$

Under the Convention on International Civil Aviation (the Chicago Convention), the Council of the International Civil Aviation Organization (ICAO) has express authority to adopt international standards and recommended practices. ${ }^{39}$ Such standards become effective upon approval by a majority of the Council's thirty-six members. ${ }^{40}$ However, a member state may opt out of its obligations if it notifies ICAO that the state finds it impracticable to comply in all respects with the standards in question. ${ }^{41}$

Under the World Health Organization (WHO) framework, the Health Assembly is authorized to adopt, by simple majority, regulations that are binding on all member states, except those that notify the WHO Director General of reservations or rejection of the regulations within a specified time. ${ }^{42}$ It is instructive to note that certain WHO regulations have the force of treaties. ${ }^{43}$

Some international organizations have used "Codes" as an effective norm-creation technique. An example is the Codex Alimentarius produced jointly by the Food and Agriculture Organization (FAO) and $\mathrm{WHO}$, which prescribes standards for all principal foods, and is widely used in the international food industry. ${ }^{44}$

Other types of instruments, such as model laws and guidelines, do not purport to codify international law, but nevertheless may be

37. Id. art. 19(5).

38. Id. art. 19(6).

39. Convention on International Civil Aviation, Dec. 7, 1944, art. 54(1), 61 Stat. 1180, 1206 15 U.N.T.S. 295 (amended 28 Oct. 1990).

40. Id. arts. 50 (composition), 52 (voting).

41. Id. art. 38 .

42. The World Health Organization, Basic Documents 7 (47th ed. 1998).

43. See Kirgis, supra note 28 , at 74 n.48. David Fidler also discusses the relation between the WHO assembly enactments and international law. DAVID P. FIDLER, INTERNATIONAL LAW AND INFECTIOUS DISEASES 58 (1999).

44. JoInt FAO/WHO CODEX Alimentarius Commission, Food AND Agriculture Organization of the United NAtions, CodeX Alimentarius: Food Labeling COMPLETE TEXTS (2000); see Kirgis, supra note 28, at 86 (noting that "Codex standards and other Codex measures are widely used by governments and by the international food trade"); see generally Oscar Schachter, The UN Legal Order: An Overview, in THE UNITED NATIONS AND INTERNATIONAL LAW, supra note 28, at 3, 8 . 
complied with by states and other entities for a variety of reasons. Examples of these are the 1985 UNCITRAL Model Law on International Commercial Arbitration ${ }^{45}$ and the 1985 FAO Guidelines for the Packaging and Storage of Pesticides. ${ }^{46}$ The 1975 Final Act of the Conference on Security and Cooperation in Europe, ${ }^{47}$ while explicitly stating that it is not a treaty, is nevertheless often cited by states as an instrument that sets out legal obligations.

The use of soft law approaches in other organizations demonstrates that there are ways of enacting international law other than through the traditional treaty method. They also show that some of those other methods have been used effectively in intergovernmental organizations. Until recently, the system of norm-making at WIPO had been the traditional treaty method. However, in order to remain a viable and credible institution, tasked with the promotion and protection of intellectual property, WIPO has had to devise new and innovative forms of norm-creation that are effective, rapid, and generally accepted by the member states. The formal rigidities and problems associated with the treaty-making process in the field of intellectual property would seem to dictate the need for a more transparent, informal, and consensual method of norm creation. In the last few years, the Secretariat of WIPO has therefore explored other means for advancing the development of international intellectual property law that could supplement the current treaty procedures.

\section{E. Proposals for Advancing the Development of Intellectual} Property Law

In 1999, the Assemblies of Member States of WIPO adopted a Resolution Concerning Provisions on the Protection of Well-Known Marks. ${ }^{48}$ In 2000, WIPO's Assemblies of Member States approved a

45. U.N. COMM'N ON INT'L TRADE LAW, UNCITRAL MODEL LAW ON INTERNATIONAL Commercial Arbitration, U.N. Doc. A/40/17, Annex I, U.N. Sales No. E.95.V.18 (1995).

46. Food and Agriculture Org. of the U.N., Guidelines for the Packaging and Storage of Pesticides (1985), available at http://www.fao.org/ag/AGP/AGPP/Pesticid/Code/Download/ pacstor.doc (last visited Nov. 27, 2001).

47. Final Act of the Conference on Security and Cooperation in Europe, adopted Aug. 1, 1975, 14 I.L.M. 1292 (1975).

48. WIPO Doc. No. A/34/13 (Aug. 4, 1999), available at http://www.wipo.int/eng/document/ govbody/wo_gb_ab/doc/a34_13.doc (last visited Nov. 27, 2001). The Resolution was aimed at clarifying and supplementing existing international protection of well-known marks, under the Paris Convention and the TRIPS Agreement. In particular, it contains a list of factors to help determine whether a mark is well known in a territory. 
Recommendation Concerning Trademark Licenses. ${ }^{49}$ In 2001, the Assemblies of Member States of WIPO adopted a Recommendation Concerning Provisions on the Protection of Marks, and Other Industrial Property Rights in Signs, on the Internet. ${ }^{50}$

The Resolution and Recommendations listed above are all part of the new 'soft law initiative' at WIPO. While the U.N. and other intergovernmental organizations have used soft law techniques for some time, their use by WIPO is a recent development. The decision to introduce such initiatives, as a means of advancing the development of intellectual property law, is largely a function of the inadequacies of the traditional treaty method described above.

The legal value of newly created norms generally depends on the content of those norms and the procedures by which they were adopted. In general, such norms would seem to be of greater precedential value if they satisfy the following criteria: (1) address matters of importance to states; (2) codify, reaffirm, or clarify certain generally accepted or widely recognized norms; (3) are adopted by consensus, by unanimity or by an overwhelming majority of the concerned member states; (4) and are adopted through a process of transparent and extensive consultations and negotiations.

The concerned WIPO member states normally analyze the value of the norms in question closely before deciding to consent or approve them. Such approval (or even acquiescence) by member states to new norms, irrespective of the instruments or documents through which such norms are adopted, obviously has great significance. In this regard, it is important to keep in mind that political commitment often plays a vital role in international law, and may be no less important than the legally binding effect of a treaty or a convention.

Under the proposed form of norm-creation, WIPO member states still have ample opportunity to influence the form and content of the norms as they are being prepared. For the sake of effectiveness and compliance with the rules in question, it is more important that

49. WIPO Doc. No. A/35/10 (July 26, 2000), available at http://www.wipo.int/eng/ document/govbody/wo_gb_ab/a34_13.doc (last visited Nov. 27, 2001). The Recommendation seeks to simplify and harmonize procedures relating to the recordal of trademark licenses. In that connection, it sets out a maximum list of indications and elements that may be required by national or regional authorities when presented with a request for recordal, cancellation, or amendment of the recordal of a license.

50. WIPO Doc. No. A/36/8 (June 18, 2001), available at http://www.wipo.int/eng/document/ govbody/wo_gb_ab/a34_13.doc (last visited Nov. 27, 2001). The Recommendation seeks to make all rights in distinctive signs that are of a territorial nature Internet-compatible, particularly trademarks, trade names, and geographical indications. 
the rules satisfy the interests and concerns of the parties involved, than that they be technically or legally binding. To the extent that the Resolutions and Recommendations are carefully negotiated, taking into account the real status, rights, and interests of concerned states and other actors on the international scene, and insofar as they contain reasonable and practical provisions for implementation, WIPO believes that they will invariably be regarded as binding instruments. There is evidence that the Resolution and Recommendations passed to date are already exercising a real influence on national law and practice. This may in part be attributable to their subject matter and the conditions in which they were adopted. In particular, they went through a long process of negotiation and extensive, but informal, consultations and therefore embody fairly representative views held by WIPO member states.

This proposed form of norm-creation is particularly suited to the field of intellectual property, which is a fast-paced and technologically driven area of law demanding detailed and specific, but rapidly generated, norms. A soft law approach has the advantage of greater flexibility as a means of keeping up with rapidly changing developments. In the field of technology, soft law instruments are easier to adopt than treaties, and may be applied immediately by states. In other words, these instruments do not in a strict sense need to be implemented via domestic legislation (e.g., in the United States, advice and consent requirements would not have to be met). In any event, it is our expectation that some of these Resolutions and Recommendations could initially be adopted as a first step towards the negotiation and conclusion of legally binding obligations, thus providing a basis for a treaty regime. Hopefully, such a supplementary means of normcreation will allow WIPO to promulgate norms more efficiently and with greater precision than could be done via the traditional treatymaking method. The challenge is how best to make WIPO and an intellectual property normative framework more effective and relevant in an attempt to increase universal compliance with fundamental intellectual property norms, while maintaining selectivity in the production of new standards.

\section{F. A Changing Playing Field}

Another important aspect of rulemaking in the field of intellectual property law is the changing nature of the participants in international legal regulation. I will use the advent of the Internet as an illustrative example. The Internet poses significant challenges to 
traditional international law paradigms. Under traditional international law, only states were regarded as competent participants in norm-making. In today's knowledge-based economy, however, that has changed dramatically. In the particular example of the Internet, perhaps the most active player is the Internet Corporation for Assigned Names and Numbers (ICANN). ${ }^{51}$ In 1998, ICANN was formed in response to a suggestion by the U.S. government that the private sector create a body to assume responsibility for certain administrative and technical aspects of the Domain Name system. This would facilitate centralization of the Internet address space allocation and root server system management functions. According to its articles of incorporation, ICANN is a nonprofit public interest corporation organized under the California Nonprofit Public Benefit Corporation Law. ${ }^{52}$ Therefore, ICANN is simply a U.S. entity and not an intergovernmental organization with global representation. ${ }^{53}$

In its relatively short existence ICANN has significantly impacted the governance of the Internet Domain Name system. It has, amongst other things, introduced seven new generic Top Level Domains (gTLDs) into the Domain Name system. ${ }^{54}$ More significantly, ICANN adopted a proposal by WIPO to establish the Uniform Domain Name Dispute Resolution Policy (UDRP), ${ }^{55}$ a mechanism which

51. See ICANN's Articles of Incorporation, available at http://www.icann.org/general/ articles.htm (last visited Nov. 24, 2001).

52. See id.

53. In response to criticism of its legitimacy, ICANN held a worldwide online vote in 2000 aimed at obtaining a large globally diverse membership. As a result of that vote, five new members were elected to the ICANN Board of Directors from each of five geographic regions: Africa, Asia/Australia/Pacific, Europe, Latin America/Caribbean, and North America. Information about the members is available at http://members.icann.org (last visited Nov. 24, 2001).

54. At its meeting in November 2000, ICANN selected the following new gTLDs: aero, .biz, .coop, .info, .museum, name, and .pro. ICANN, Preliminary Report: Second Annual Meeting and Organizational Meetings of the ICANN Board, 16 November 2000, available at http:// www.icann.org/minutes/prelim-report-16nov00.htm\#Second Annual Meeting (last visited Nov. 24, 2001).

55. As explained in the Report of the Second WIPO Internet Domain Name Process, however, the UDRP

does not seek to regulate the whole universe of the interface between trademarks and domain names, but only to implement the lowest common denominator of internationally agreed and accepted principles concerning the abuse of trademarks. The exercise was less about legislation than about the efficient application of existing law in a multijurisdictional and cross-territorial space.

WIPO, The Recognition of Rights and the Use of Names in the Internet Domain Name System: Report of the Second WIPO Internet Domain Name Process, September 3, 2001, at 31, available at http://wipo2.wipo.int/process2/report/pdf/report.pdf (last visited Nov. 24, 2001). The Second WIPO Internet Domain Name Process involves more difficult questions that have far-reaching 
has resulted in the implementation of a successful administrative system for resolving domain name disputes involving trademarks and a system of best practices for domain name registration authorities, designed to avoid such disputes. ${ }^{56}$ The UDRP is now used worldwide and has, in effect, set clear standards for the resolution of intellectual property disputes in cyberspace. Clearly, the global reach and technological supremacy of the United States has not only made it an indispensable actor in international law, but has also made some U.S.based non-governmental entities indispensable players in certain aspects of international legal regulation. The success of ICANN demonstrates that non-governmental entities are also playing a significant role in norm-making and legal regulation in intellectual property and other legal areas.

\section{CONCLUSION}

I have sought in this paper to provide a brief overview of the challenges posed by rapid advances in technology as an example of some of the issues facing the World Intellectual Property Organization in the constantly evolving field of intellectual property law.

The increasing pace of globalization, the ever-rapid advances in technology, and the desire of international organizations to maintain their relevance by adopting rapid and effective means of rulemaking that are politically acceptable to their member states is an issue that is likely to test the capacity of international organizations in the next few years. In the particular context of intellectual property law the World Intellectual Property Organization seems, thus far, to be coping very well with this challenge.

implications for the manner in which the international community creates law in this completely new area. See id.

56. In its first year of operation alone, the UDRP of WIPO received some 2000 cases. Several of these cases were submitted by well-known celebrities, including Julia Roberts, Bruce Springsteen, Venus and Serena Williams, Isabelle Adjani, and Madonna, as well as major corporations, including Microsoft Corporation, General Electric Company, and Nokia Corporation. 